\section{Annual Meeting Perspectives}

\section{Participation by Women in the 1998 APSA Meeting}

Martin Gruberg, University of Wisconsin, Oshkosh

\begin{tabular}{|c|c|c|c|}
\hline \multicolumn{4}{|c|}{ CHAIRPERSONS } \\
\hline Year & Total & Women & $\%$ \\
\hline 1971 & 154 & 12 & 7.8 \\
\hline 1981 & 137 & 16 & 11.7 \\
\hline 1991 & 439 & 107 & 24.4 \\
\hline 1992 & 463 & 106 & 22.9 \\
\hline 1993 & 452 & 115 & 25.4 \\
\hline 1994 & 509 & 164 & 32.2 \\
\hline 1995 & 480 & 134 & 27.9 \\
\hline 1996 & 517 & 136 & 26.3 \\
\hline 1997 & 503 & 143 & 28.4 \\
\hline 1998 & 521 & 115 & 22.1 \\
\hline \multicolumn{4}{|c|}{ PAPERGIVERS } \\
\hline 1971 & 552 & 43 & 7.8 \\
\hline 1981 & 520 & 98 & 18.8 \\
\hline 1991 & 1940 & 512 & 26.4 \\
\hline 1992 & 1986 & 445 & 22.5 \\
\hline 1993 & 2053 & 525 & 25.6 \\
\hline 1994 & 2200 & 576 & 26.2 \\
\hline 1995 & 2160 & 598 & 27.7 \\
\hline 1996 & 2414 & 781 & 32.4 \\
\hline 1997 & 2419 & 669 & 27.7 \\
\hline 1998 & 2825 & 811 & 28.7 \\
\hline \multicolumn{4}{|c|}{ DISCUSSANTS } \\
\hline 1971 & 184 & 13 & 7.1 \\
\hline 1981 & 161 & 28 & 17.4 \\
\hline 1991 & 455 & 120 & 26.4 \\
\hline 1992 & 568 & 118 & 20.8 \\
\hline 1993 & 521 & 152 & 29.2 \\
\hline 1994 & 594 & 157 & 26.4 \\
\hline 1995 & 583 & 157 & 26.9 \\
\hline 1996 & 574 & 142 & 24.7 \\
\hline 1997 & 575 & 161 & 28.0 \\
\hline 1998 & 708 & 183 & 25.8 \\
\hline
\end{tabular}

Poster sessions are now an established part of the programs. Women were $24.5 \%$ of the poster presenters in 1998 (135 of 547).

As l've noted previously, where women head divisions or panels, there is a greater likelihood of other women being selected for program contributions. This year we had a female chairing the Program Committee. In 1998, 17 of the 47 division persons were women (36.2\%) (cf. 1995: 38.8\%; 1996: $30.06 \%$; 1997: $37.3 \%$ ). The divisions they headed had women as $31.8 \%$ ( 68 of 214 ) of the chairpersons, $38.8 \%$ (414 of 1067) of the papergivers, and $36.7 \%$ (91 of 248) of the discussants (cf. 1995: $30.7 \%$, 34.2\%, 31.0\%; 1996: 26.1\%, 35.1\%, 29.8\%; 1997: 35.4\%, 32.1\%, 31.4\%).

The convention divisions led by women had $59.1 \%$ of the convention's female panel chairs, $51.0 \%$ of the papergivers, and $49.7 \%$ of its discussants (cf. $1995: 44.0 \%, 48.0 \%, 42.0 \% ; 1996$ : $40.4 \%, 50.7 \%$; $1997: 60.1 \%, 54.0 \%, 53.4 \%)$. Women-chaired panels had $41.1 \%$ female paper givers and $49.4 \%$ female discussants (cf. 1995: 41.0, 42.5\%; 1996: 38.7\%, 33.9\%; 1997: $37.7 \%, 43.0 \%)$. These constituted $33.8 \%$ of the women giving papers at the 1998 convention and $43.7 \%$ of the women serving as discussants (Cf. 1995: 40.8\%, 43.3\%; 1996: $30.9 \%$, $30.3 \% ; 1997: 38.0 \%, 40.4 \%)$.

The divisions with the weakest female representation in 1998 were those on Formal Political Theory, Politics and History, Political Methodology, Comparative Politics, International Security, International Security and Arms Control, Domestic Sources of Foreign Policy, Conflict Processes, Urban Politics, Political Organizations and Parties, and Elections and Voting Behavior.

Among the predominantly female panels were those on Privacy and Democracy, "Private" Values and "Public" Life, Europeanization and Domestic Change II, Substitutability in Foreign Policy Women as Legislators: Impact and Influence, New Theory and New Methods for Policy Implementation: The View from the Street, The States and "Morality" Politics*, Mobilizing Women's Communities I: The Americas, Mobilizing Women's Communities II: Africa and the Middle East, Gender and Political Communications I and II, Gender, Elections and Public Opinion I: Comparative*, Feminism and Political Community Women in the Global Community: The European Union and NAFTA Gender. Public Policy and the State IV: Comparative Abortion Policy, Mobilizing Women's Communities III: Sisters Doin' It For Themselves, and Gender and Transformational Politics.
Sniderman, Stanford University, and Edward G. Carmines, Indiana University shared the 1998 Gladys M. Kammerer Award for their work Reaching Beyond Race (Harvard University Press). The Kammerer Award is presented for the best political science publication in the field of U.S. national policy.

The Victoria Schuck Award, for the best book published in the previous year on women and politics, went to Uma Narayan, Vassar College, for Dislocating Cultures: Identities, Traditions, and Third World Feminism (Routledge). University of California, San Diego faculty member Gary W. Cox won the Woodrow Wilson Foundation Award for his book Making Votes Count: Strategic Coordination in the World's Electoral Systems (Cambridge University Press). Cox's book was also named both Best Book in Political Economy and Best Book in Comparative Politics by those respective Organized Sections later in the week (see article on Organized Sections prizes in this issue of $P S$ ).

Full citations for all awards appear in "The Gazette" in this issue of PS. For information on 1999 APSA Awards visit the APSA web site (www.apsanet.org/Awards/).

\section{Graduate Students Attend Meeting with APSA Assistance}

In a continuing effort to assist graduate students wishing to participate in the Annual Meeting, the Association awarded 27 grants through the Advanced Graduate Student Travel Grant Program. Funded by APSA, winners were selected from a pool of over 100 applicants. All those who applied were to present a paper or poster as part of the Annual Meeting Program.

Since the grants were first awarded in 1994, over 100 doctoral students from the United States have been funded. The number of applications submitted for consideration has risen over $40 \%$. At the 1998 Annual Meeting in Boston, graduate students delivered papers on approximately 675 panels and roundtables and were well represented among the 350 scholars presenting posters. 